\title{
ウロキナーゼに混在する蛋白分解酵素 抒よび蛋白分解酵素阻害因子の分析*
}

\author{
宮 谷勝 明**
}

ウロキナーゼ ${ }^{1,2)}$ は尿中に存在するプラスミノゲンア クチベーターでトリプシン,3) ストレプトキナーゼ4 や ブロメライン5)などと同じように，プラスミノゲンを活 性化してプラスミンを生成させる酵素として知られてい る.

この酵素は臨床的に血栓溶解剂として広く用いられ， また，近年では抗癌剤との併用療法も行われ注目されて いる.

これに対して, 臨床検查領域ではウロキナーゼ標準物 質としてフィブリン体分解法, エステル分解法, さらに はカゼイン分解法6) などの他に，ニーグロブリン分画に ウロキナーゼを添加してプラスミノゲンを測定するとき にも用いられている.?

このウロキナーゼには夾雑物として凝固促進物質, 蛋 白など8,9) が指摘されていることに注目して，著者は 8 社のウロキナーゼを実験の対象に用いて生物学的に蛋白 分解酵素を, 免疫化学的に蛋白分解醏素阻害因子を中心 に検索を行うとともに，併せて共存因子について考察を 加えたので，その成績を報告する．

\section{実 験 方 法}

1. 試 薬

フィブリノゲン: Behringer のヒトフィブリノゲン $250 \mathrm{mg} / \mathrm{vial}$ を用いた.

トロンビン: Calbiochem. のヒトトロンビン500単位/ vial のものを用いた。

抗七卜蛋白分解酵素阻害因子家鬼血清: Behringwerke の抗 $\alpha_{1}$-アンチキモトリプシン，抗インター $\alpha_{1}$ ・トリプシ ンインヒビター，抗 $\mathrm{C} 1 \mathrm{~s}$-インヒビターを用いた。

蛋白分解酵素阻害因子の標準物質：Behringwerke の 蛋白標準血漿と蛋白標準血清 B-I, B-II，B-III を用い
た。

アガロース : 半井化学薬品のアガロース A-37.

防腐㓮：アジ化ナトリウム．

緩衝液： $\mathrm{pH}$ 8.6，イオン強度 0.05 のベロナール緩衝 液を用いた。

2. 試 料

ウロキナーゼ：持田製薬（Lot No. B 950），日立化成 (Lot No. UKI 516), 帝国臟器 (Lot No. KO 91), 興 和 (Lot No. BG $805 \mathrm{M}$ ), 鐘紡 (Lot No. 0038N), ミ ドリ十字 (Lot No. 048RR5), 大塚製薬 (Lot No. 7A 82U1), 大五栄養化学 (Lot No. KM200) を実験時に 乾燥重量で $30 \mathrm{mg} / \mathrm{ml}$ 溶液になるように生理食塩水を用 いて溶解した。

3. フィブリン平板の作製 ${ }^{10)}$

$200 \mathrm{mg} / \mathrm{dl}$ ヒトフィブリノゲン溶液 $8.0 \mathrm{ml}$ を直径 85 $\mathrm{mm}$ (内径 $35 \mathrm{~mm}$ は空間), 高さ $4 \mathrm{~mm}$ でいわゆるド ーナツ型のプラスチック製平板に入れ，ついで 20 単位/ $\mathrm{ml}$ ヒトトロンビン溶液を $0.2 \mathrm{ml}$ 加えてすばやく回転 させてよく混和した後, 厚さ $2 \mathrm{~mm}$ のフィブリン平板を 作製した。

4. 免疫拡散板の作製11)

アガロース $1.2 \mathrm{~g}$, アジ化ナトリウム $100 \mathrm{mg}$ をべロ ナール緩衝液 ( $\mathrm{pH} \mathrm{8.6, \mu} \mathrm{0.05)} 100 \mathrm{ml}$ に混和した後, 水浴中で加温して溶解した．溶解したアガロースが $56^{\circ} \mathrm{C}$ になったとき，抗血清を抗 $\alpha_{1}$-アンチキモトリプシンで は濃度 $6.0 \%$ ，抗インター $\alpha$-トリプシンインヒビターで は濃度 $5.0 \%$, 抗 $\mathrm{C} 1 \mathrm{~s}-$ インヒビターでは濃度 $7.0 \%$ の割 合で混和し，水平にしたプラスチック製の 7 検体用平板 に 1 検体あたり $0.3 \mathrm{ml}$ ずつ分注して厚さ $1 \mathrm{~mm}$ の平板 を作製した。ついで，ゲル化したアガローースの中央に直 径 $2 \mathrm{~mm}$ の小孔をあけた。

* Analysis of fibrinolytic factors and proteinase inhibitors contained in urokinase reagents.

** Katsuaki Miyatani, 宇治黄集病院臨床検査科.

（受付１980年10月22日） 


\section{（354）生物物理化学}

\section{5. 蛋白分解酵素の湘定法10)}

フィブリン平板上に各種の $30 \mathrm{mg} / \mathrm{ml}$ ウロキナーゼ溶 液をマイクロシリンジで正確に $2.0 \mu 1$ 滴下し, 静かに 蓋をして室温に18時間放置した後, 形成された溶解輪の 直径を測定用スケール（2.0〜 $14.0 \mathrm{~mm})$ で測定した.

\section{6. 蛋白分解酵素阻害因子の測定法}

3 種の免疫拡散板の小孔に各種の $30 \mathrm{mg} / \mathrm{ml}$ ウロキナ 一ゼ溶液と 3 濃度の蛋白標準血漿をマイクロシリンジで 正確に $3.0 \mu \mathrm{l}$ 分注してから,静かに蓋をして湿潤箱に入 れ, 室温に48時間放置した後, 沈降輸の直径を測定用ス ケール (2.0〜14.0 mm) で $0.1 \mathrm{~mm}$ の単位まで測定し た。

得られた定量值は同時に測定した検量線から求めた。 $\alpha_{1}$ •アンチトリプシン，アンチトロンビンIIII, $\alpha_{2}$-マク ウグロブリンの測定には Behringwerke の 1 元平板免疫

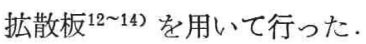

\section{実 験 成 績}

1. ウロキナーゼに混在する蛋白分解酵素

各種のウロキナーゼ溶液を試料としてフィブリン溶解 面積の測定を行った.

Fig. 1 に示したよらに，直接，フィブリンを分解した のはミドリ十字のみであった. 他のウロキナーゼによる 溶解輪は認められなかった。

2. ウロキナーゼに混在する蛋白分解酵素阻害因子 各種のウロキナーゼ溶液を抗原として6 種の蛋白分解 酵素阻害因子の測定を行った。

Table 1 に示したように, 帝国臟器, 大五栄養化学で

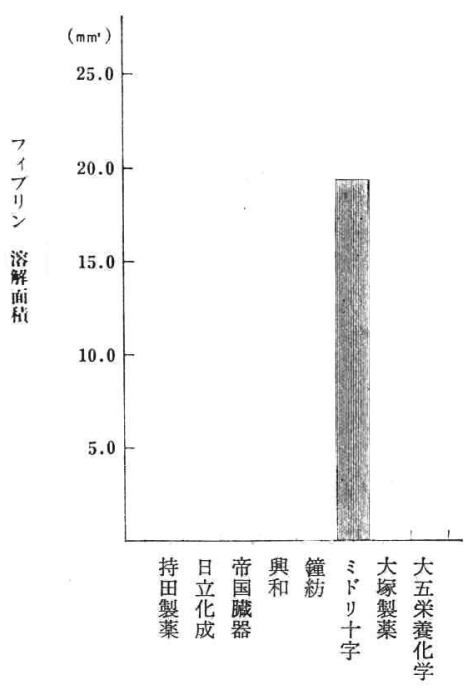

Fig. 1. ウロキナーゼに混存する蛋白分解酵素.

は C1s-インヒビター， ミドリ十字では $\alpha_{1}$ ・アンチトリプ シンが定量されたた。

3. ウロキナーゼに混在する蛋白分解酵素阻害因子の 占める割合

ウロキナーゼに混在する阻害因子蛋白量の総蛋白量に 対する割合を Table 1 の結果より算出したところ，帝 国葴器の C1s-インヒビターでは $0.3 \%$, ミドリ十字の $\alpha_{1}$-アンチトリプシンと大五栄養化学の C1s-インヒビタ ーではいずれも $0.2 \%$ であった.

Table 1. ウロキナーゼに混在する蛋白分解酵素阻害因子.

\begin{tabular}{|c|c|c|c|c|c|c|c|c|}
\hline メーカー & $\begin{array}{l}\text { 持 } \\
\text { 田 } \\
\text { 製 } \\
\text { 薬 }\end{array}$ & $\begin{array}{l}\text { 日 } \\
\text { 立 } \\
\text { 化 } \\
\text { 成 }\end{array}$ & $\begin{array}{l}\text { 帝 } \\
\text { 国 } \\
\text { 臟 } \\
\text { 器 }\end{array}$ & 興 & $\begin{array}{l}\text { 鐘 } \\
\text { 紡 }\end{array}$ & $\begin{array}{c}\Sigma \\
F \\
\text { y } \\
+ \\
+ \\
\text { 字 }\end{array}$ & $\begin{array}{l}\text { 大 } \\
\text { 塚 } \\
\text { 製 } \\
\text { 薬 }\end{array}$ & $\begin{array}{l}\text { 大化 } \\
\text { 五 } \\
\text { 栄 } \\
\text { 養学 }\end{array}$ \\
\hline 類 & B 950 & UKI5116P & KO91 & B G $805 \mathrm{M}$ & $0038 \mathrm{~N}$ & 048R R 5 & $7 \mathrm{~A} 82 \mathrm{U} 1$ & KM200 \\
\hline$\alpha_{1}$ •アンチトリプシン & - & - & - & - & - & 6.4 & - & - \\
\hline$\alpha_{1}$ •アンチキモトリプシン & - & - & - & - & - & - & - & - \\
\hline アンチトロンビンIII & - & - & - & - & - & - & - & - \\
\hline 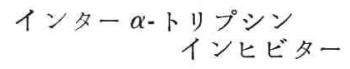 & 一 & - & - & - & - & - & - & - \\
\hline$\alpha_{2}$-マクログロブリン & - & - & - & - & - & - & - & - \\
\hline C1s-インヒビター & 一 & - & 7.4 & - & - & - & - & 6.2 \\
\hline
\end{tabular}




\section{考察および総括}

ウロキナーゼの 分画は必ずしも容易でないとされる が，血栓溶解剤として治療に用いられることから，分画

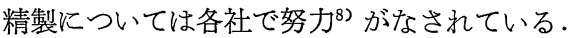

ウロキナーゼは治療薬として役割がきわめて大きな比 重を占めているだけでなく，臨床検査領域に执いてもウ ロキナーゼ標準物質( ${ }^{6)}$ や線溶活性の測定試薬 ${ }^{7)}$ として広 く用いられている.特に，線溶系酵素を測定するときに 考慮を払らべき因子として，蛋白分解酵素ととの阻害因 子の混在であろらと考えられる.

市販ウロキナーゼをアフィニテイクロマトグラフィに

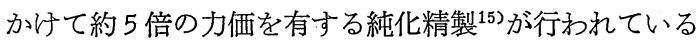
が，この精製技術を臨床検査領域に拈いて応用するまで に至っていないのが現状であろう.

したがって，高純度のウロキナーゼを安価に入手する ことが現在のところきわめて難しいために，どらしても ウロキナーゼ以外の因子の出来るだけ混在していない製 剂を選択する必要にせをられよう。

まず, プラスミノゲンの含まれていないヒトフィブリ ン平板上で各種のウロキナーゼについて蛋白分解酵素の 検索を試みた。

ウロキナーゼはプラスミノゲンを活性して, 生成され たプラスミンの作用によってフィブリンを分解すること から，ミドリ十字のウロキナーゼの中にはフィブリンを 分解する何らかの蛋白分解酵素が混在していることを示 しているものとみられる・

ついで，各種のウロキナーゼの中に蛋白分解酵素阻害 因子が混在しているか否かについて吟味した成績では， 帝国臓器と大五栄養化学のウロキナーゼにC1s-インヒビ

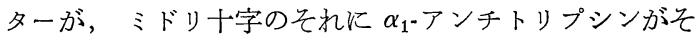
れぞれ定量された。

さらに，各種のウロキナーゼに混在する蛋白分解酵素 阻害因子の存在量として表わした場合, 帝国臓器のC1sインヒビターでは0.3\%, ミドリ十字の $\alpha_{1}$-アンチトリプ シンと大五栄養化学の C1s-インヒビターではいずれも $0.2 \%$ 占めていた。

いずれにしてもこのような成績から，ウロキナーゼの
精製を進めていく過程でどうしても収量が著しく減少す るために，価格の点をも考虑して残存しているとみられ る蛋白の中に $\alpha_{1}$-アンチトリプシンと C1s-インヒビター が除去しきれないで混在していたとも考えられる.

6 種の蛋白分解酵素阻害因子のらちで, $\alpha_{1}$-アンチトリ プシン，アンチトロンビン III， $\alpha_{2}$-マクログロブリン, C1s-インヒビターのプラスミンに対する阻害作用 ${ }^{16,17)}$ が 認められることを考合わせれば, ウロキナーゼに混在

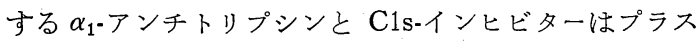
ミン作用機構に対して関与するものとみられるので, こ れらの因子の混入していないウロキナーゼ製剤が選ばれ るべきであろら .

\section{文献}

1) Williams, J.R.B. : British. J. Exp. Patho., $32: 530,1951$.

2) Sobel, G.W. et al. : Am. J. Physiol., 171 : 768, 1952.

3) Hagan, J. J. et al. : J. Biol. Chem., 235 : 1005, 1960.

4) Christensen, L.R. : J. Gen. Physiol., $28: 363$, 1945.

5) Opher, A. W. and Miller, J.M. : Exp. Med. Surg., $22: 246,1964$.

6）安部 英: 綜合臨床，18:1734，1969.

7) 松岡松三, 桜川信男 : 臨床血液, 7:513, 1966.

8 ）延原正弘：MR C ウロキナーゼ研究会（西日本 大会)，持田製薬，東京，p.1，1977.

9）五十嵐紀子：MR Cウロキナーゼ研究会（東日 本大会)，持田製薬，東京，p.1，1977.

10）宮谷勝明, 福井 巌 : 臨床病理, $19: 641$, 1971.

11) Mancini, G. et al. : Immunochem., $2: 235$, 1965.

12）宮谷勝明, 福井 瞰 : 衛生検査, $24: 291$, 1975.

13）宮谷勝明他：臨床検查，19:80，1975.

14) 宮谷勝明他: 臨床検査, $18: 317,1974$.

15）田村禎通, 藤井節郎：臨床病理, $24: 301$, 1976.

16）寺野由剛: 化学の領域, 105号(増刊), 1, 1974 .

17）青木延雄, 諸井将明 : 代謝, 14 : 1099，1977. 